\title{
Rice (Oryza sativa $L$ ) cultivation in the highest elevation of the world
}

MN Paudel ${ }^{*}$

\begin{abstract}
Jumla is one of the 75 districts in the midwestern hills of Nepal. Rice (Oryza sativa L) cultivation in Jumla ranges from 2,400 to $3,050 \mathrm{~m}$ altitude, which is the highest elevation in the world. The highest elevation at $3,050 \mathrm{~m}$ is Chhumjul of Jumla, a record altitude, where rice is cultivated in Nepal. Jumli Marshi, a Japonica variety of indigenous rice, having cold tolerant gene, is probably cultivated since 1,300 years ago in Jumla in the bank of the Tila river. Improved rice varieties were tested in the Jumla valley by the Nepal Agricultural Research Council (NARC). In 2002, two improved rice varieties Chandannath-1 and Chandannath-3 were released for temperate region of Jumla and Karnali zone. Productivity of rice in Jumla is $1.7 \mathrm{mt} / \mathrm{ha}$ almost $40 \%$ lower than that of national average of $2.97 \mathrm{t} / \mathrm{ha}$. Low productivity of rice is mainly due to the constraints of many biotic, abiotic and socioeconomic factors. Food security in the food deficit region of the Karnali zone could be sustained by increasing rice productivity in the Jumla region where perennial irrigation is available round the year. Whole of the Jumla region is unique place with respect to rice cultivation in the highest altitude of the world. The practice of rice cultivation in Jumla could be a remarkable activity for boosting agro-tourism in the agrarian country like Nepal. Rice cultivation in Jumla is quite unique from the rice cultivation even in the same range of temperate region. Such a typical organic rice production system in the highest elevation of the world needs immediate attention of all institutions and authorities concerned to conserve it for the future generation as well. Jumla, the temperate region, is also affected by the impact of global warming thereby receding water level in the Tila river and its tributaries flowing in the Jumla valleys during rice growing season (March - October). Attempts have been made to document ethno-culture, socio-economic and cultural practices of rice cultivation in the highest elevation in the world.
\end{abstract}

Key words: Jumla region, rice cultivation, cold tolerant variety, highest elevation

\section{Introduction}

Nepal is located in South Asia in coordinates of $28^{\circ} \mathrm{N}$ and $84^{0} \mathrm{E}$ and it is situated in between China in the north and India in other sides. Geographically, Nepal is divided into five main regions; the Himalaya, high hills, mid-hills, Siwalik and, and Terai. However, agroecologically, Nepal is divided into three domains viz; hills (both mid and high hills), Siwalik and Terai. These regions run east to west almost paralleling each other. Nepal, noted for her

\footnotetext{
* Outreach Research Division, Khumaltar, NARC, mnpaudel@yahoo.com
} 
majestic Himalayas, the roof of the world, Sagarmatha, the Mount Everest 8,848 meter above mean sea level $(\mathrm{m})$ in the north and the lowest point Kechanakal $60 \mathrm{~m}$ in the south. The Himalayas which in Sanskrit means the home of snow, the water towers, which supply water to the Indo-gangetic plain of Indian subcontinent, are the proud of the mountainous and hilly country, Nepal. Its shape is roughly rectangular, about 650 kilometers long and about 200 kilometers wide, and comprises a total of 147,181 square kilometers area. Population of Nepal is 27.5 million with an average growth rate of $2.25 \%$ which is $1.2 \%$ higher than that of agriculture growth rate (MoAC, 2010). Climate of Nepal varies from cool summer to severe winter that serves as micro museum of the world (Paudel, 2009).

\section{Rice in Nepal}

Of the 75 districts in Nepal, rice is grown in 73 districts except Mustang and Manang of trans-Himalayan region. It is to say that even the people of Nepal who do not eat rice as their main diet used to say that they ate bhat (cooked rice) which strictly implies to rice for eating rice is prestigious compared to other foods. Hence, rice is culturally and socially associated to Nepalese society and role of rice is more important than ever from cradle to crave of Nepalese ethno-culture.

Climate of Nepal varies from cool summers and severe winters in the north to subtropical summers and mild winters in the south. In Nepal, rice has been cultivating in extreme altitude ranging from $60 \mathrm{~m}$ of eastern Terai, Kechanakal of Jhapa to $3,050 \mathrm{~m}$ of temperate region, Chhumchour of Jumla, the highest elevation in the world. Rice in Nepal is number one crop both in area (1.481 million ha) and production (4.023 million ton) with a productivity of 2.716 ton/ha (MoAC, 2010). In 2009/10, share of agriculture and forestry for national Gross Domestic Product (GDP) was $33.03 \%$ of which the share of rice was $20.75 \%$ whereas contribution of rice at current price of NRs 30,000/ton alone becomes NRs 1 , 20,690 million which is $10.2 \%$ of total GDP. Likewise, out of the total cultivated area of 3.091 million ha, rice cultivation occupies $47.91 \%$ in Nepal. Therefore, rice holds very important position both in agriculture and economy of Nepal. In 2009/10, Nepal is facing a net food deficit of 0.316 million metric ton which is mainly attributed to the low production of rice 0.501 million metric ton to that of last fiscal year 2008/09 (MoAC, 2010).

\section{Methodology}

The study was done by reviewing available literatures through desk study and internet browsing, personal communication with senior citizens, researchers, extension personnel, and direct field observation by the author in Jumla during rice growing month of June in 2009 (Ashad 2067 BS). 


\section{Results and discussion}

\section{Jumla, a unique place for rice cultivation}

Of the five development region, Jumla falls under the high hills of the midwestern region among the 75 districts in Nepal. According to the annual district development program of Jumla (2008/09) its profile is as follow: It lies in $28^{0} 58^{\prime \prime}$ to $29^{\circ} 30^{\prime \prime} \mathrm{N}$ latitude and $81^{\circ} 51^{\prime \prime}$ to $82^{0} 35^{\prime \prime}$ E longitude with an area of 2,531 sq km, altitude varies from 2,134 to 6,424 m, annual average rainfall of $800 \mathrm{~mm}$, maximum temperature of $30^{\circ} \mathrm{c}$ in June and minimum temperature of up to $-14^{\circ} \mathrm{c}$ in January and relative humidity of 51 to $73 \%$ during the year. The population of Jumla is 10, 5001 having the density of 35 persons per square kilometer. Total land is $2,54,365$ ha of which $16 \%$ is cultivable whereas rice occupies about $19 \%$ of the cultivated land (Shrestha, 2002).

It has been established that Jumla is the place where rice is cultivated in the highest altitude in the world (Sapkota et al; 2010). However, there are variations in reporting what exactly is the point where rice is cultivated in the highest place in the world. Nevertheless, the altitude range of Jumla for rice cultivation varies from about 2,400-3,050 m and whole of this range has been the highest elevation of rice growing domains cited by different literatures in the world. A synoptic view of those literatures has been cited to make clear about the mention of highest elevation of rice cultivation in the world. Tao Dayun et al; (1996) reported that rice was evaluated in Jumla at 2,600 m; at the banks of the Tila River at 2,370 m is the highest rice growing areas in the world (http://Jumla-Humla-html). Jumla, on the banks of the Tila River at $2,370 \mathrm{~m}$, is one of the highest rice growing areas in the world (http:/aviatravelnepal.com/Jumla-Humla-Nepal.html). Sinja village in Jumla is also known for the highest paddy farming in the world (http://allnepaltreks.com). Until 2006, rice was the main crop in Chhumchour Jiulo (Figure 1), 2,850 m of Jumla (http://yubabahas.com/). Jumla, a high-altitude site $(2,200-3,000 \mathrm{~m})$, identified rice landraces with different names that differed in phenotype and were adapted to the extreme high-altitude environment- Jumli Marshi (Bajcharya, et al; 2006). The Tila river at 2,370 m, Jumla, is one of the highest ricegrowing areas of the world, where the unique 'red'-rice is grown (http://www.itreknepal. com). The International Rice Research Institute (IRRI) has confirmed that "Jumli Marshi" (paddy cultivated in the hilly district of Jumla) is one of the coldest tolerant varieties of paddy found in the world (Poudel, 2005). Haatsija (3,000 m) and Chhumchour (3000 m) of Jumla are probably the highest elevation in the world for rice farming (Shrestha, 2002, Sapkota et al; 2010), Chhumchour (3,000 m) of Jumla (is the highest altitude where rice is grown (Baidhyay, 2008), in Jumla $(>2,600 \mathrm{~m}$ ) rice is cultivated in the highest altitude in the world (Paudel and Thakur, 2009), and Chhumjul of Chhumchour (3050 m), Jumla (Bjujel et al, 2011), the highest altitude in the world for rice cultivation. Similarly, Mallick (1981) described that rice in Nepal was cultivated since 1500-2800 which was cited in the Vedic literatures. 


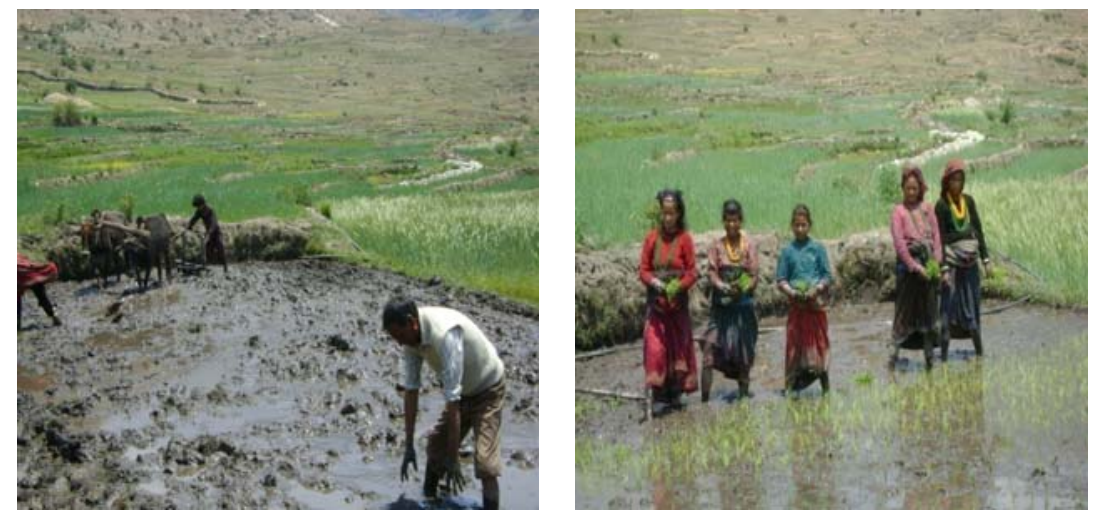

Figure 1. Rice cultivation at Chhumchour Jul (3,050 m) of Jumla, the highest elevation in the world

\section{Rice variety grown in Jumla valley}

It has been reported that about 1,300 years ago one Hindu Saint Chandannath brought a handful of rice from the Kashmir valley and gave it to the local priest to cultivate rice in the present day Jumla valley (Shrestha, 2002). The place where Saint Chandannath tested rice variety Jumli Marshi for the first time in Jumla was at Tatopani called Lachhojyulo locally and then rice spread successfully across Jumla valley. It is believed by the inhabitant of Jumla that at Lachhojyulo whatever the weather condition is rice production does not fluctuates and production is same as was produced by the Saint Chandannath for the first time about 1,300 years ago. That is why, in Jumla, rice paddies areas are called Jul or Jula even today. This concept has not been changed since the time when Saint Chandannath introduced rice in Jumla valley. Before the introduction of improved varieties of rice in Jumla, Jumli Marshi (Figure 2) was the only rice variety grown in the area.
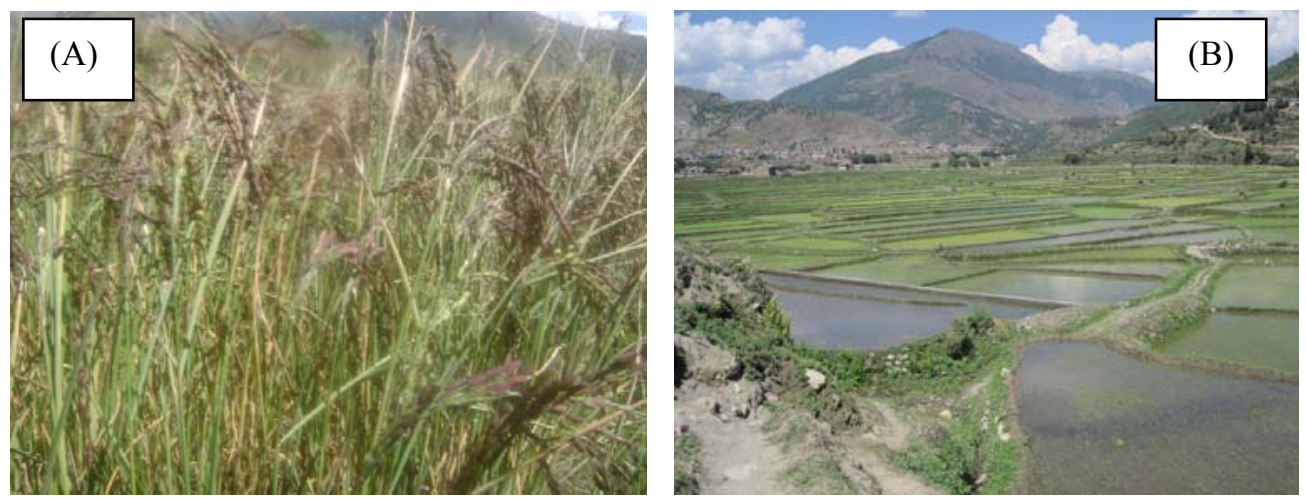

Figure 2. Jumli Marshi rice variety (A) at dough stage and rice paddies (B) during $\mathbf{1}^{\text {st }}$ week of June in 2010 at the bank of the Tila river, Jumla valley 
In 2002, improved rice varieties Chandannath-1 (Jhingling-78) and Chandannath-3 (Yungen-1) were released by the Nepal Agricultural Research Council (NARC) after testing them in Jumla condition for several years. These are the Chinese origin of Japonica rice varieties received from the International Rice Research Institute (IRRI), the Philippines. Jumli Marshi and Chandannath-1 are red rice while Chandannath-3 is white rice. The productivity of these improved varieties in Jumla condition was recorded up to 6.0 t/ha (NARC, 2007) in the research station while in the farmers' field their productivity was about 2.5 to $3.5 \mathrm{t} / \mathrm{ha}$ which is almost double of the productivity of local variety, Jumli Marshi (1.7 t/ha) in the Jumla condition. All of these rice varieties are cold tolerant ones and these have posed cold tolerant gene to thrive in cold temperate condition. These varieties mature in about 190 days after seeding. Nowadays, other improved cold tolerant varieties such as Chhomro Local and many more rice lines have been introduced in the Jumla valley by NARC.

\section{Size of holdings}

Size of land holding of rice farmers in Jumla varies from less than 1 ropani (500 square meters) to 10-15 ropani. Social status is measured on the basis of size of holding of rice in Jumla. More the size of rice farms higher the social status and vice versa. More than $90 \%$ of the paddy fields are owned by high castes (Bhramin, kshetri, Newar, and Thakuri) and around $10 \%$ belong to dalit (professional caste such as shoe maker, smiths, tailors) and marginalized groups in whole of the Jumla district. Rice fields are very expensive and these are the most fertile land in the Jumla areas. Due to openings of road from Surkhet, these fertile lands have been started converting to the residential areas. If proper measures are not taken timely by the authority concerned to check converting rice fields into non-agricultural purpose Jumla will soon meet the fate as that of Kathmandu valley where most productive land of the country have been converted into jungle of concrete. This will further aggravate the food insecurity scenario of the Karnali region.

\section{Social attachment of rice with ethno-culture}

Rice per se in Nepalese culture deserves special privilege in general and Jumla and the Karnali region in particular. The author made a trip to Jumla and had intensive discussion with senior citizens of the area and noted cultural association of rice in the region. Culturally rice is attached from cradle to crave. Of course, rice in Jumla is used as bhat (cooked rice), khatte (popped rice), khir (rice pudding), selroti (ring bread), madaroti (bread prepared from the porridge of broken rice), laddu (popped rice smeared with molasses and balled), jand/raksi (local beer /whisky) preparation, tika (milled/dehusked rice smeared with yoghurt and maroon/violet color put on the forehead as the blessing by the senior member of the family) in religious function, auspicious occasion such as ritual worship of gods/goddess, child birth, marriage, good omen during out going from home and home coming from outside, and offerings to gods and goddess during auspicious occasions such as puja (daily worshipping of gods and goddess in most of the households). Rice straw is used for making 
mats and many local products for household use as well. Also it is very important fodder for animals during fodder lean period of winter season. For every feasta such as dasain and tihar (the greatest festivals of Hindus), death and birth ceremony, rice is a must in Jumla and in the Karnali region. Without rice no ceremony is completed. Hence, rice in the Karnali region is one of the important parts of ethno-culture and livelihood of the people therein.

One of the most important aspects of rice cultivation is that many of the male members of the families in Jumla region used to go out in search of jobs to Indian cities and urban areas of Nepal. On the very day of seed soaking of rice on $25^{\text {th }}$ March $\left(12^{\text {th }}\right.$ Chaitra) if outgoing members do not return home it is a bad omen for the family thereby household members in Jumla think that there might have gone something wrong to their loved ones and he might have passed away. This implies that how rice is attached socially and culturally in the Jumla region.

\section{Rice cultivation practices in the highest altitude}

Rice cultivation in Jumla do not match with rice cultivation elsewhere, hence it is quite interesting to understand the rice cultivation practice of Jumla. Description of some of the unique practices of rice cultivation has been tried herewith.

\section{Time and practice of nursery bed raising}

The practice of rice cultivation is unique in Chhumchour $(3,050 \mathrm{~m})$ and Dillichour $(2,750$ $\mathrm{m})$, the highest elevations of rice growing in Jumla. On March $25^{\text {th }}$ (Chaitra $\left.12^{\text {th }}\right)$ every year rice seed is soaked in jute bags and incubated near fire place for 4-5 days by covering them with gunny/ jute bags whereas in Chandannath and Sija $(2,600 \mathrm{~m})$ this practice of seed soaking and incubation is done during March 25 to April 2. Same practice of seed incubation as followed in Chhumchour and Dillichour is followed in other parts of Jumla before sowing seeds in wet seed beds. This practice initiates seed activity leading to emergence when seed is broadcast in the wet nursery beds. During this period, the maximum ambient temperature of Jumla is about $27-28^{\circ} \mathrm{c}$ whereas minimum of about 5-6 ${ }^{0} \mathrm{c}$. On April 3, sprouted seeds taken from the bags are broadcast in the wet nursery beds. In the nursery beds, compost prepared from farm yard manure (FYM) and leaf litters are spread evenly covering the sprouted seeds. Dried cow dung is burnt and the ashes from the burnt dung are thinly spread over the nursery as munuring. Application of thus burnt ashes is used 1-2 times in the nursery beds. This practice of applying FYM and ashes in the nursery beds help maintain temperature sufficient for emergence and growth of seedlings in the nursery beds. Soils of Jumla valley are light and shallow. The soil is alluvial sandy loam and low to medium in organic matter content and soil reaction is acidic ranging from $\mathrm{pH}$ value of 4.5 to 5.5 . 


\section{Field preparation and transplanting}

Rice is transplanted in the well puddled fields. First ploughing is done immediately after harvest of barley and second ploughing follows puddling at the time of transplanting. Ploughing with local plough is strictly done by male while transplanting is the main job of women. Operations such as seedling pulling and transporting them to the field, and composting are also done by the female as well. Bund making, filed preparation, and planking/leveling are done by men only. Leveling is done by wooden plank called Bingato locally. About one month old seedling is transplanted which starts from May 28 to June 12 (second week of Jestha to end of Jestha) in the well puddled rice field. Transplanting is done randomly keeping one seedling per hill with a distance of 5-7 $\mathrm{cm}$ hill to hill. In Jumla, rice is grown in rice-barley cropping pattern.

\section{Irrigation and intercultural operation}

Continuous flooding irrigation by gravity flow is practiced in paddy field which is a normal practice of irrigation right after transplanting to the end of August. There is cold injury in every terrace riser and rice does not come into heading due to cold injury in such areas of the terraces. After the end of August, irrigation is ceased for about 45 days and rice paddies are allowed to dry up during this period. Rice is harvested up to the end of October.

First manual weeding is done 15-20 days after transplanting (DAT) by female only whereas weeds floated on water are taken away by male by using wooden plank. Second hand weeding follows 30-40 DAT by using hand and iron rake to uproot deep rooted weeds which infest rice fields. Mostly two manual weeding are sufficient to curb down weed infestation of irrigated rice in Jumla. In 2009, Jumla was declared an organic farming district. No chemical inputs are used in whole of the Jumla district. Hence, there is no use of weedicides to control weeds. However, before 2009 there were records that farmers in Jumla used to apply some chemicals such as fertilizers, pesticides and weedicides in rice farming too.

\section{Intercropping of soybean in the rice bunds}

At the time of transplanting, rice bunds are prepared in the irrigated paddy fields. Within a week of transplanting, local soybean varieties such as Muse (black soybean), Sathiya (maturing in 60 days) and bikase (improved soybean) are sown in the paddy bunds. These soybeans are very good ally or intercropped with irrigated rice in the Jumla condition. Harvesting of soybean coincide with the harvesting of rice.

\section{Plant protection}

Rice in Jumla has been suffering from many anomalies such as insect, pests and diseases. The important insects are borer (Chylopartelus sp) and bug (Leptocorisa sp) which infest rice during vegetative and reproductive phase, respectively. All varieties such as Jumli Marshi, Chandannath-1 and Chandananth-3 are susceptible to these pests. The important 
diseases of rice in Jumla are blast, foot rot, sheath blight, and to some extent bacterial leaf blight. Improved variety Chandannath-1 and Chandannath-3 are tolerant to these diseases whereas local Jumli Marshi is susceptible to them. Aside from these insect pests and disease, rice in Jumla suffers from sterility mainly due to cold injury and nutrient deficiency. The problem of sterility is more severe on local rice than that of improved variety.

\section{Harvesting and storage}

Harvesting, threshing and transportation from the field to the threshing yard are done by both the sexes. Rice harvesting in Jumla is just like a local feasta of the region. It generally starts from the first week of October and ends up to the second week of this month. New rice harvesting starts by offering puja on the first day of Ghatasthapana (sacred earthen pot is kept filling water on it by offering whole heartily to goddess Durga during nine days of Durga Puja). In October, the maximum temperature is about $22-23{ }^{\circ} \mathrm{c}$ whereas the minimum temperature is $2-3^{0} \mathrm{c}$ (ARS, Jumla, 2009). Harvesting is done by cutting the hills leaving 5-7 $\mathrm{cm}$ stubble for rice straw is very valuable fodder to animals. After harvesting, rice is staked in small bundle making easier for manual threshing. Threshed straw is treaded by bullocks so that there is complete exhausting of grains from the panicles.

Grains are staked in jute bags or they are stored in wooden granary, earthen pots or by making trenches of about 6' $\times 4$ 'x3' dimension. Such trenches are made inside the house and some bedding materials are put at the surface of the pit so as to protect the rice from damping off. Tadis patra (Abis spectabalis) leaves are bedded in the bottom of the pit and in the side wall cow dung plus clay soil plus litters plastered are pasted on the mouth of pits which is covered with wooden plank lid. Rice grains are filled in these pits and taken out whenever necessary for consumption. This practice of storing rice in the pits is followed by big farmers only. Small farmers store rice in small local containers and consume in a short period of time whereas big farmers store rice up to 2-3 years for older the rice higher the social prestige and vice versa. It was reported that taste of rice becomes more palatable even after 2-3 years in the temperate condition. Rice moth (Citrotraga cerella) and rice weevil (Sitophylus orizae) are the storage pests of rice.

\section{Challenge and opportunities of rice cultivation in Jumla}

Whole of the Karnali zone (Dolpa, Mugu, Humla, Jumla and Kalikot districts) in the mid western region is facing food shortage chronically. The productivity of rice in this region including Jumla is $1.7 \mathrm{mt} / \mathrm{ha}$ compared to the national productivity of $2.716 \mathrm{ton} / \mathrm{ha}$ (MoAC, 2010). Evidences showed that Jumla is one of the fertile lands in this area and rice is the main crop of the region. The productivity of rice is very low and it could be substantially increased provided improved cultivation practice is followed. There is ample room to supplement food to the Karnali zone by increasing production of rice in Jumla. Also, availability of plenty of perennial waters for rice cultivation in Jumla makes it a favorable place for irrigated rice. Aside from the input shortage of production, these days active work 
force has been migrating outward in search of jobs and farming has become a burden to women, children and elderly who are resided in the households. According to the information received from the senior citizens of Jumla, because of climate change water level in the Tila river and its tributary has been receding in the recent years and there is the problem of rice cultivation mainly due to shortage of labor and inputs. There are problem of insects, pests, and diseases of rice in Jumla. In 2009, Jumla was declared an organic district by the District Development Committee, the local government, without considering the negative consequences of rice production in the area. And legally after 2009, there are no availability of chemical fertilizers and pesticides in Jumla. It seems that there are still chances of declining rice production in the Jumla region due to all of such bottle necks. Hence, these constraints should be addressed by placing effective thrust on research in the Agriculture Research Station (ARS) situated at Vijayanagar, the head quarter of Jumla to immediately address these constraints. Technology developed by the ARS, Jumla could then be effectively disseminated by the service providers concerned in the Karnali region.

\section{Conclusion}

In hills and mountain to address food insecurity, the Government of Nepal has been air lifting rice in general and Karnali region in particular. To feed the hungry mouths, emphasis should be given to increase local food self sufficiency because the Interim Constitution of Nepal (2007) has guaranteed food sovereignty as the constitution rights of citizens. Therefore, the Government of Nepal should put more thrust on research for development in Jumla to sustain food availability in the Karnali region as a whole. This could be done by placing high priority on improved rice production. Emphasis should also be given for adopting improved rice cultivation practice in Jumla where the nature has bestowed rich potentiality of rice cultivation. Now, Chhumchour, 3,050 m, the highest elevation in the world where rice is cultivated could be devoid of rice cultivation due to many constraints such as labor shortage, untimely onset and exhaust of rainfall and worst of is that water receding in the rivers because of the effect of climate change. Therefore, it is the responsibility of the Government of Nepal and the Nepal Agricultural Research Council (NARC) to conserve Jumla region as a unique place of rice cultivation. This will help develop Jumla as an eco-tourism centre for cold tolerant rice cultivation in the world. In this aspect, all the concerned authorities nationally and internally should take initiatives to conserve rice cultivation in the highest elevation of the world, Jumla valley. At the end, Jumla could be an ideal lab to develop cold tolerant rice varieties of the temperate region to address the impact of climate change in the Himalayan region as well for impact of climate change is more pronounced in the temperate region including the Himalaya and Japonica rice growing belt as a whole. This could not only be a contribution to the temperate region of Nepal but also to the whole of temperate belt of the world so far as Japonica species of rice cultivation is concerned. 


\section{Acknowledgements}

The author is thankful to Mr. RB Bhujel, Senior Scientist/ Chief of ARS, Jumla for providing undocumented information about rice cultivation in Jumla region and giving photograph of rice transplanting at Chhumchour. He is also equally grateful to Mr. PM Mahat, Technical Officer, ARS Jumla, for providing ethno-cultural importance of rice in Karnali region and making contact with some of the senior citizens for tracing historical information about rice cultivation in the Jumla valley. Last but not the least, he bows to the sage Chandannath who introduced rice in the Jumla valley 1300 years ago for enhancing socio-economic status of the Karnali region as a whole.

\section{References}

Annual district development program, Jumla. 2008/09. Office of the district development council, Jumla, Nepal.

ARS (Agriultural Research Station), Jumla. 2009. Annual Report of ARS, Jumla 2009/10.

Bhujel, RB, PM Mahat, and CB Rana. 2011. Jumlama Dhan Kheti (Nepali). Agricultural Research Station. Bijayanagar, Jumla, 2067 BS. 23p.

http://www. aviatravelnepal.com/Jumla-Humla-Nepal.html retrieved on 3rd Aug 2010.

http://www. Jumla-Humla-Nepal_highest rice growing place.html retrieved on $5^{\text {th }} \mathrm{Jul} 2010$.

http://www.allnepaltreks.com, retrieved on $9^{\text {th }}$ May 2010.

http://www.itreknepal.com retrieved on $15^{\text {th }}$ Aug 2010. http://yubabahas.com/ retrieved on $15^{\text {th }}$ Aug 2010.

Interim Constitution of Nepal. 2007. Government of Nepal, Singh Durbar, Kathmandu, Nepal.

J Bajracharya, KA Steele, DI Jarvis, BR Sthapit and JR Witcombe. 2006. Rice landrace diversity in Nepal: Variability of agro-morphological traits and SSR markers in landraces from a highaltitude site. Field Crops Research 95:2-3, 325-327.

Mallick, RN. 1981. Rice in Nepal, Kala Prakashan, Kathmandu. 216 p.

MoAC (Ministry of Agriculture and Cooperatives). 2010. Selected indicators of Nepalese agriculture and population. Agri-business promotion and statistics, division, Kathmandu, Nepal.

NARC (Nepal Agricultural Research Council). 2007. Released and registered crop varieties in Nepal 1960-2007. Communication, publication, and documentation division, NARC, Kathmandu, Nepal.

Paudel, MN and NS Thakur. 2009. Rice (Oryza sativa) in Nepalese agriculture. Hamro Sampada (Nepali), national monthly, Year 8 Volume 10, Pp 84-86.

Paudel, MN. 2009. Effect of climate change and its consequences in food production in Nepal. Agron $J N$ 1: 40-49.

Poudel, KC. 2005. Thematic report on Nepal's mountain biodiversity. Ministry of Forests and Soil Conservation (MFSC), His Majesty's Government of Nepal (HMG/Nepal). 
Sapkota, S, MN Paudel, NS Thakur, MB Nepali, and R Neupane. 2010. Effect of climate change on rice production: A case of six VDCs in Jumla district. Nepal Journal of Science and Technology 11: 57-62.

Shrestha, GL. 2002. Special techniques of organic rice farming in Jumla, Nepal - A unique rice culture in the high Himalayas. $1^{\text {st }}$ RDA/ARNOA international conference on development of basic standard for organic rice cultivation, 12-15 November, 2002. RDA and Dankook Univ. Kore.

Tao Dayun, Fengyi, H Guifen, Y Jiangyi. 1996. Introduction and utilisation of CIRAD upland rice cultivars in China. In C. Poisson \& J. Rakotoarisoa (Eeds). Rice for highlands. Proceedings of the International Conference on Rice for Highlands, Antananarivo, Madagascar, 29 Mar. - 5 April 1996. Montpellier, France, CIRAD. 269 pp http://agroecologie.cirad.fr retrieved on $15^{\text {th }}$ Aug 2010. 